\title{
The effect of the season on some blood metabolites and haptoglobin in dairy cows during postpartum period
}

\author{
Daniela Alberghina', Giuseppe Piccione', Stefania Casella', Michele Panzera', Massimo \\ Morgante ${ }^{2}$ and Matteo Gianesella ${ }^{2}$ \\ 'Department of Experimental Sciences and Applied Biotechnology, Faculty of Veterinary Medicine, University of \\ Messina, Messina, Italy, ${ }^{2}$ Department of Veterinary Clinical Sciences, Faculty of Veterinary Medicine, University of \\ Padova, Padua, Italy
}

\begin{abstract}
The aim of this study was to evaluate the effect of the season (ambient temperature and relative humidity) on some blood metabolites in dairy cows during postpartum period. Blood samples were collected from 195 clinically healthy dairy cows of 8 Italian dairy herds in spring (April-May $15.5 \pm 4^{\circ} \mathrm{C}$ and $69.5 \pm 0.7 \%$ ), summer (June-July $23 \pm 1.5^{\circ} \mathrm{C}$ and $69 \pm 1.3 \%$ ) and autumn (September-October $17 \pm 2^{\circ} \mathrm{C}$ and $72.5 \pm 2 \%$ ). Total proteins, albumin, globulins, urea, glucose, triglycerides, total cholesterol, non-esterified fatty acids, $\beta$-hydroxybutyrate and haptoglobin were analysed. One-way repeated measures analysis of variance (ANOVA) showed a significant effect of the season $(P<0.05)$ on all studied parameters, except to the packed cell volume, globulins and $\beta$-hydroxybutyrate. A positive significant correlation was found only between albumin and total cholesterol in summer $(r=0.39 ; P<0.01)$ and autumn $(r=0.40 ; P<0.001)$. These results indicated the influence of the season on blood metabolites in dairy cows during postpartum period.
\end{abstract}

Keywords: dairy cows, haematochemical parameters, haptoglobin, postpartum period

Abbreviations: $\beta$-HBA: $\beta$-hydroxybutyrate; NEFA: non-esterified fatty acids; PCV: packed cell volume 


\section{Introduction}

The postpartum period is a period of great metabolic stress in which dairy cows with more severe and prolonged negative energy balance have an increased risk of disease and culling (Rajala-Schultz \& Grohn 1999, Butler 2005). It is not clear how much of the reduction in performance can be attributed or accounted directly (hyperthermia) or indirectly (reduced to feed intake) to heat stress (Bernabucci et al. 2010). The performance of animals, in fact, is the result of the interaction between different factors that may exert negative effects on farm animal welfare, performance and health (Nardone et al. 2006). Reduction in reproductive performance of lactating cows during hot climate has been well documented (Thatcher et al. 2010) and is associated with a decreased thermoregulatory competence of lactating dairy cows, partially due to intensive genetic selection for high milk production (Al-Katanani et al. 1999). The influence of the moderate variation of climate conditions on metabolic parameters of dairy cows has been less investigated. Animals react to disturbances of their homeostasis with a set of physiological changes known as acute phase response (Piňeiro et al. 2003). This response is associated with changes in lipid and glucose metabolism (Hardordottir et al. 1994) and in some serum proteins such as the acute phase proteins (Petersen et al. 2004). For example haptoglobin, an acute phase protein released from hepatocytes in response to tissue injury or infection (Murata et al. 2004), acts as a potent immunosuppressor of lymphocyte function and as an antioxidant (Sadrzadeh et al. 2004). It has been demonstrated that its values increase in dairy cows during postpartum period and its high concentrations have been associated with an increased incidence of endometritis (Sheldon et al. 2001, Williams et al. 2005) or with other inflammatory problems (Dubuc et al. 2010). In dairy cows, the haptoglobin levels have been also evaluated in relation to thermal stress showing the relationship between the changes and the different climatic conditions (Giannetto et al. 2011). In dairy cows, impaired glucose production would likely lead to increased adipose tissue mobilisation, elevated plasma nonesterified fatty acids (NEFA) and increased $\beta$-hydroxybutyrate ( $\beta$-HBA) production by the liver. In dairy cows the key metabolic analytes used as indicators of negative energy balance and subclinical ketosis are properly NEFA and $\beta$-HBA (Oetzel 2004). In this respect the aim of the present study was to evaluate the concentrations of some blood metabolites, together with haptoglobin, during postpartum period in different seasons.

\section{Material and methods}

The aim was carried out on 195 multiparous Holstein Frisian dairy cows during postpartum period ( $n=60$ in 3rd-4th week, $n=70$ in 5th-8th week, $n=65$ in 9th-10th week), selected from eight Italian intensive dairy herds $\left(45^{\circ} 24^{\prime} \mathrm{N}, 11^{\circ} 48^{\prime} \mathrm{E}\right)$. All housing and care conditions were conformed to the standards recommended by the Guide for the Care and Use of Laboratory Animals, Directive 2010/63/EU and Directive 1998/58/EU. Thermal and hygrometric records were carried out by means of a data logger (Gemini, Chichester, UK). The average values, minimum and maximum of temperature and relative humidity recorded in the experimental period are reported in Table 1. Table 2 shows the chemical composition of diets used during the experimental period. Blood samples were collected on each animal from the 8th April to the 28th May (spring), from the 11th June to the 26th July (summer) and from 1the 9th 
September to the 31st October (autumn). Samples were collected from different subjects for each period as follows: (spring $n=60$, summer $n=65$ subjects, autumn $n=70$ ). In each period dairy cows were equally distributed for the postpartum week. The body condition score was recorded as the average of two scores assigned independently by two evaluators using a 1 to 5 scale according to Edmonson et al. (1989). Dairy herds had a milk production of about $10000 \mathrm{~kg}$ per year. Blood samples were collected by jugular venipuncture into a plastic syringe between 08.00 and 09.00 a.m. The small volume of blood was then transferred into capillary heparin tubes for packed cell volume (PCV) determination by microhematocrit centrifuge (Select-A-Fuge 24, Bio-Dynamics, IA, USA). The remaining whole blood was centrifuged at $1350 \times \mathrm{g}$ for $10 \mathrm{~min}$. The obtained sera were stored, within one hour from withdrawal and stored at $-20^{\circ} \mathrm{C}$ until analysis. The serum concentration of total proteins (biuret reaction), albumin (bromcresol green method, BCG), urea (UV kinetic with urease and glutamate dehydrogenase, GLDH) glucose (hexokinase, G6PDH reaction), total cholesterol (cholesterol oxidase, CHOD-PAP reaction), triglycerides (enzymatic, glycerol-3-phosphate-oxidase), NEFA (enzymatic colorimetricmethod), $\beta$-HBA (enzymatic colorimetric method) were assessed using commercial kits by automated analyser Boehringer Mannheim/HITACHI 911 (Roche, Basel, Switzerland). The determination of haptoglobin concentrations was performed by the method of enzyme linked immunosorbent assay using ELISA kits (Tridelta Development, Ltd., Wicklow, Ireland). The globulin values were calculated by subtracting the values of albumin from the corresponding values of total proteins. One-way repeated measures analysis of variance (ANOVA) was applied to evaluate the statistical differences due to the season. Bonferroni's multiple comparison test was applied for post hoc comparison. $P$-values $<0.05$ were considered statistically significant.

Table 1

Average values, minimum and maximum values of ambient temperature and relative humidity recorded during experimental period

\begin{tabular}{|c|c|c|c|c|c|c|}
\hline \multirow[t]{3}{*}{ Season } & \multicolumn{6}{|c|}{ Environmental conditions } \\
\hline & \multicolumn{3}{|c|}{ Ambient temperature, ${ }^{\circ} \mathrm{C}$} & \multicolumn{3}{|c|}{ Relative humidity, $\%$} \\
\hline & Min & Max & Mean & Min & Max & Mean \\
\hline Spring & 11.50 & 19.50 & 15.50 & 68.00 & 71.00 & 69.50 \\
\hline Summer & 21.50 & 24.50 & 23.00 & 66.10 & 72.10 & 69.10 \\
\hline Autumn & 15.00 & 19.00 & 17.00 & 70.50 & 74.50 & 72.50 \\
\hline
\end{tabular}

Table 2

Chemical composition (\%) of diet used during the experimental period

Chemical composition of diet

Crude protein

Ethreal extract

Ash

Neutral detergent fibre

Non fibre carbohydrates

Dry Metter Degradable

Acid detergent fibre

Starch

Dietary cation-anion balance
16.59

6.01

7.42

30.17

38.81

68.48

20.37

28.46

49.39 
All the data were analysed using Statistica 8 software (StatSoft, Inc., Tulsa, OK, USA). For individual values of all parameters, a linear regression model $(\mathrm{y}=\mathrm{a}+\mathrm{bx})$ was applied in order to determine the correlation degree between the studied parameters and the correlation coefficient ( $r$ ) was determined.

\section{Results and discussion}

There were no statistical differences among periods on PCV $(32 \pm 3.38 \%)$ and body condition score $(3.07 \pm 0.26)$ in dairy cows. Total proteins and albumin were significantly higher in spring $(P<0.05)$ than in summer and autumn $(P<0.05)$. Significant lower urea and glucose concentrations were measured in summer respect to spring and autumn $(P<0.05)$. Triglycerid concentrations significantly decreased in spring compared to autumn $(P<0.05)$, total cholesterol concentrations significantly increased in spring in comparison with summer and autumn $(P<0.05)$, NEFA concentrations significantly decreased in autumn compared with spring and summer $(P<0.05)$. Haptoglobin values were significantly higher in summer than in autumn $(P<0.05)$. Table 3 shows the average values of the studied parameters, expressed in their conventional units of measurement, with standard deviations and statistical significances observed in 195 Holstein Frisian dairy cows during postpartum period and during different seasons. A positive significant correlation was found only between albumin and total cholesterol in summer $(r=0.39 ; P<0.01)$ and autumn $(r=0.40 ; P<0.001)$.

Table 3

Average values $( \pm S D)$ of all studied parameters in dairy cows during postpartum and obtained during different seasons

\begin{tabular}{lccc}
\hline Parameters & Spring & $\begin{array}{c}\text { Experimental period } \\
\text { Summer }\end{array}$ & Autumn \\
\hline Total proteins, g/L & $85.44 \pm 6.30^{\mathrm{a}}$ & $80.54 \pm 7.49$ & $80.96 \pm 8.28$ \\
Albumin, $\mathrm{g} / \mathrm{L}$ & $37.67 \pm 2.74^{\mathrm{a}}$ & $34.76 \pm 3.63$ & $35.01 \pm 3.23$ \\
Globulins, $\mathrm{g} / \mathrm{L}$ & $47.77 \pm 7.90$ & $45.78 \pm 8.31$ & $45.99 \pm 8.70$ \\
Urea, $\mathrm{mg} / \mathrm{dL}$ & $25.74 \pm 6.48$ & $22.92 \pm 5.82^{\mathrm{c}}$ & $25.80 \pm 6.18$ \\
Glucose, $\mathrm{mmol} / \mathrm{L}$ & $3.04 \pm 0.50^{\mathrm{b}}$ & $2.89 \pm 0.35^{\mathrm{c}}$ & $3.15 \pm 0.44$ \\
Triglycerides, $\mathrm{mmol} / \mathrm{L}$ & $0.12 \pm 0.04^{\mathrm{c}}$ & $0.13 \pm 0.03$ & $0.14 \pm 0.03$ \\
Total cholesterol, $\mathrm{mmol} / \mathrm{L}$ & $4.69 \pm 1.04^{\mathrm{a}}$ & $4.11 \pm 1.20$ & $4.11 \pm 1.11$ \\
NEFA, $\mathrm{mmol} / \mathrm{L}$ & $0.30 \pm 0.16^{\mathrm{c}}$ & $0.31 \pm 0.17^{\mathrm{c}}$ & $0.24 \pm 0.11$ \\
$\beta$-HBA, $\mathrm{mmol} / \mathrm{L}$ & $0.67 \pm 0.29$ & $0.68 \pm 0.49$ & $0.60 \pm 0.22$ \\
Haptoglobin, $\mathrm{g} / \mathrm{L}$ & $0.12 \pm 0.072$ & $0.14 \pm 0.091^{\mathrm{c}}$ & $0.10 \pm 0.059$ \\
\hline
\end{tabular}

avs summer and autumn $P<0.05$, bvs summer $P<0.05$, 'vs autumn $P<0.05$

These results showed that metabolic profiles in dairy cows during postpartum period could be influenced by climate conditions. Because PCV was unaffected by periods, the differences observed for total proteins and albumin concentrations were not a consequence of dehydration or plasma volume expansion. The increase of total proteins and albumin in spring is probably correlated to the vegetation available inthis period. In fact, a previous study showed a direct relationship between protein intake and serum albumin in cows (Hoffman et al. 2001). So, probably the lower concentrations of total proteins, albumin and urea in summer could be caused by a decrease of nitrogen intake by feed. In addition, the 
concentrations of total cholesterol were significantly higher in spring than in summer and autumn in relation to higher concentrations of albumin found in this period. In human a positive correlation was found between serum albumin and serum cholesterol (Gillum \& Makuc 1992) and albumin plays a significant role in cholesterol transfer between cells and lipoproteins (Zhao \& Marcel 1996). The correlation found in our study in summer and autumn could confirm that also bovine albumin is involved in cholesterol metabolism. Serum glucose in dairy cows is probably derived almost exclusively from gluconeogenesis and lower glucose concentrations in summer suggest that gluconeogenesis is less effective to increase blood glucose than in other periods. Haptoglobin was also influenced by the experimental period with significantly higher concentrations in summer. The effect of climatic conditions on haptoglobin in dairy cows is controversial: some authors did not find a season influence on its concentrations (Chan et al. 2004), while other authors found higher concentrations in summer than in winter (Wenz et al. 2010). It is believed that serum haptoglobin in cows could be involved in the regulation of lipid metabolism (Kanno \& Katoh 2001). In our study the patterns of haptoglobin and NEFA were similar among periods. Haptoglobin is also an effective marker of fatty liver (Ametaj et al. 2002). Fat infiltration into the liver may also decreases glucose, total proteins, albumin and urea concentrations (West 1990). These last blood biochemical components were significantly lower in summer. The high concentrations of serum triglycerides observed in autumn, together with lower concentrations of NEFA, could be due to a lower lipid utilisation by peripheral tissues in this period. Moreover, the higher concentrations of glucose in autumn could be related to lower concentrations of NEFA and $\beta-H B A$. High concentrations of $\beta-H B A$ are a consequence of an increased gluconeogenesis pathway that does not permit the full metabolisation of acetylcoenzyme A by Krebs cycle. These findings could indicate that also moderate environmental conditions influence some blood biochemical components in dairy cows during postpartum period. Further investigation should confirm whether different environmental factors such as altitude, latitude and photoperiod could influence metabolism in different breeds and lead to different predispositions for the development of metabolic diseases and culling risk.

\section{References}

Al-Katanani YM, Webb DW, Hansen PJ (1999) Factors Affecting Seasonal Variation in 90-Day Nonreturn Rate To First Service in Lactating Holstein Cows in a Hot Climate. J Dairy Sci 82, 2611-2616

Ametaj BN (2005) A New Understanding of the Causes of Fatty Liver in Dairy Cows. Adv Dairy Tech 17, 97-112

Bernabucci U, Lacetera N, Baumgard LH, Rhoads RP, Ronchi B, Nardone A (2010) Metabolic and hormonal acclimation to heat stress in domesticated ruminants. Animal 4, 1167-1183

Butler WR (2005) Inhibition of ovulation in the postpartum cow and the lactating sow. Livest Prod Sci 98, 5-12

Chan JP, Chu CC, Fung HP, Chuang ST, Lin YC, Chu RM, Lee SL (2004) Serum Haptoglobin Concentration in Cattle. J Vet Med Sci 66, 43-46

Dubuc J, Duffield TF, Leslie KE, Walton JS, LeBlanc SJ (2010) Risk factors for postpartum uterine diseases in dairy cows. J Dairy Sci 93, 5764-5771

Giannetto C, Giudice E, Casella S, Fazio F, Alberghina D, Piccione G (2011) [Termal stress and acute phase protein blodd levels in cows]. Large Anim Rev 17, 3-6 [in Italian]

Gillum RF, Makuc DM (1992) Serum albumin, coronary heart disease, and death. Am Heart J 123, 507-513

Hardardottir I, Grunfeld C, Feingold KR (1994) Effects of endotoxin and cytokines on lipid metabolism. Curr Opin Lipidol 5, 207-215 
Hoffman PC, Esser NM, Bauman LM, Denzine SL, Engstrom M, Chester-Jones H (2001) Short Communication: Effect of Dietary Protein on Growth and Nitrogen Balance of Holstein Heifers. J Dairy Sci 4, 843-847

Kanno H, Katoh N (2001) Analysis by Enzyme-Linked Immunosorbent Assay and 2-Dimensional Electrophoresis of Haptoglobin in the High-Density Lipoprotein Fraction in Cows. J Vet Med Sci 63, 61-66

Murata H, Shimada N, Yoshioka M (2004) Current research on acute phase proteins in veterinary diagnosis: an overview. Vet J 168, 28-40

Nardone A, Ronchi B, Lacetera N, Bernabucci U (2006) Climatic Effects on Productive Traits in Livestock. Vet Res Commun 30 (Suppl.), 75-81

Oetzel GR (2004) Monitoring and testing dairy herds for metabolic disease. Vet Clin North Am Food Anim Pract $20,651-674$

Petersen HH, Nielsen JP, Heegaard PMH (2004) Application of acute phase protein measurements in veterinary clinical chemistry. Vet Res 35, 163-187

Piňeiro M, Alava MA, Lampreave F (2003) Acute phase proteins in different species: a review. Fourth European Colloquium on Acute Phase Proteins, Segovia, Spain 77-82

Rajala-Schultz PJ, Gröhn YT (1999) Culling of dairy cows. Part I. Effects of diseases on culling in Finnish Ayrshire cows. Prev Vet Med 41, 195-208

Sadrzadeh SMH, Bozorgmehr J (2004) Haptoglobin Phenotypes in Health and Disorders. Am J Clin Pathol 121, 97-104

Sheldon IM, Noakes DE, Rycroft A, Dobson H (2001) Acute phase protein responses to uterine bacterial contamination in cattle after calving. Vet Rec 148, 172-175

Thatcher WW, Flamenbaum I, Block J, Bilby TR (2010) Interrelationships of Heat Stress and Reproduction in Lactating Dairy Cows. High Plains Dairy Conference, 45-60

Wenz JR, Fox LK, Muller FJ, Rinaldi M, Zeng R, Bannerman DD (2010) Factors associated with concentrations of select cytokine and acute phase proteins in dairy cows with naturally occurring clinical mastitis. J Dairy Sci 93, 2458-2470

West HJ (1990) Effect on liver function of acetonaemia and the fat cow syndrome in cattle. Res Vet Sci 48, 221-227

Williams EJ, Fischer DP, Pfeiffer DU, England GCW, Noakes DE, Dobson H, Sheldon IM (2005) Clinical evaluation of postpartum vaginal mucus reflects uterine bacterial infection and the immune response in cattle. Theriogenology 63, 102-117

Zhao Y, Marcel YL (1996) Serum Albumin Is a Significant Intermediate in Cholesterol Transfer between Cells and Lipoproteins. Biochemistry 35, 7174-7180 